\title{
Vehicular fuel composition and atmospheric emissions in South China: Hong Kong, Macau, Guangzhou, and Zhuhai
}

\author{
W. Y. Tsai ${ }^{1}$, L. Y. Chan ${ }^{1}$, D. R. Blake ${ }^{2}$, and K. W. Chu ${ }^{1}$ \\ ${ }^{1}$ Department of Civil and Structural Engineering, The Hong Kong Polytechnic University, Kowloon, Hong Kong \\ ${ }^{2}$ Department of Chemistry, University of California, Irvine, CA, USA
}

Received: 7 February 2006 - Published in Atmos. Chem. Phys. Discuss.: 10 May 2006

Revised: 7 July 2006 - Accepted: 31 July 2006 - Published: 8 August 2006

\begin{abstract}
Vehicular emission is an important source of air pollutants in urban cities in the Pearl River Delta (PRD) region of South China. In order to study the impact of evaporative loss of vehicular fuel on air quality, several commonly used fuel samples were collected in four main cities in the PRD region - Hong Kong, Guangzhou, Macau and Zhuhai, and analyzed for their volatile organic compounds (VOCs) composition. Source profiles of vapors of the vehicular fuels used in these cities were constructed and are believed to be the first reported for the PRD region. The $\mathrm{C}_{8}-\mathrm{C}_{10}$ hydrocarbons were the main constituents of diesel. Different from diesel, gasoline used in the PRD region was mainly comprised of lighter $\mathrm{C}_{4}-\mathrm{C}_{7}$ hydrocarbons, with toluene and i-pentane being the two most abundant species. The toluene content in the Hong Kong and Macau gasoline samples were higher than that in Guangzhou and Zhuhai, while the reverse was true for the benzene content. The benzene levels in Guangzhou and Zhuhai exceeded the maximum allowable benzene levels for Mainland China unleaded gasoline. Liquefied Petroleum Gas (LPG) samples were collected only in Hong Kong and were comprised mainly of n-butane, propane and i-butane. Traffic samples indicated that evaporative loss and vehicular combustion were the primary contributors to elevated VOC levels in roadside atmospheres. Significant i-pentane and toluene concentrations were observed in roadside atmospheres in all four cities. Ratio of i-pentane in gasoline vapors to that in roadside samples were calculated and this showed that the degree of evaporative loss were higher in Guangzhou and Zhuhai than that in Hong Kong and Macau. We suggest the difference is due to the better maintenance and more new cars in Hong Kong and Macau. From tunnel samples collected in Hong Kong in two different years, we found that the relative amount of propane, i-butane, and nbutane increased between 2001 to 2003, consistent with the
\end{abstract}

Correspondence to: L. Y. Chan

(celychan@polyu.edu.hk)
$40 \%$ increase in LPG fueled vehicles. Propane to butanes ratios were calculated for LPG samples and tunnels samples, and the comparable ratios illustrated the LPG leakages from LPG fueled vehicles crossing the tunnel.

\section{Introduction}

Volatile Organic Compounds (VOCs) emitted by vehicles (either by combustion or leakage of unburned gasoline) contribute to the formation of peroxyacetyl nitrate (PAN) and photochemical smog, and have potential adverse effects on human health. Photochemical smog is now an everyday occurrence in many urban areas throughout the world. Smog is a mixture of secondary pollutants such as ozone, nitrogen dioxide, nitric acid, aldehydes and other organic compounds, formed from photochemical reactions between nitrogen oxides and hydrocarbons. Specific VOCs, such as benzene and 1,3-butadiene, may also lead to an increase in diseases such as lung cancer and leukaemia. Perry and Gee (1995) found that 1,3-butadiene was rarely found in gasoline but was commonly found in the exhaust gas, and concluded that combustion of olefins were a primary source of 1,3-butadiene.

Other than exhaust emission and gasoline evaporative loss, the importance of Liquefied Petroleum Gas (LPG) leakage on urban air quality has been reported (Blake and Rowland, 1995; Chen et al., 2001). Blake and Rowland (1995) found that leakage of unburned LPG played a significant role in ozone formation in Mexico City. Chen et al. (2001) concluded that roughly $5 \%$ of the LPG that was sold in Santiago, Chile leaked in its unburned form to the atmosphere. The leakage of unburned LPG was found to be a major source of nonmethane hydrocarbons (NMHCs) in the air of Santiago.

The main fuels used in the four PRD cities - Hong Kong Special Administrative Region, Macau Special Administrative Region, Zhuhai Special Economic Zone, and Guangzhou (capital city of Guangdong Province) - were examined in this

Published by Copernicus GmbH on behalf of the European Geosciences Union. 


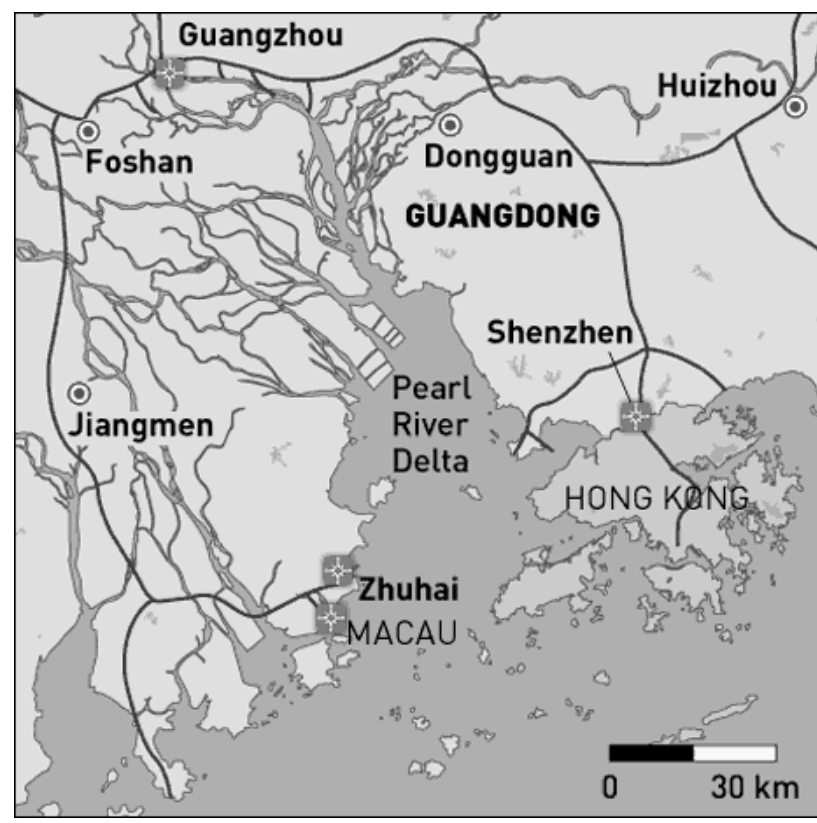

Fig. 1. Locations of the major PRD cities, samples were collected in Hong Kong, Guangzhou, Macau, and Zhuhai.

study (Fig. 1). These four cities are major cities in the region and were chosen because of their different political systems. Guangzhou and Zhuhai follows the environmental policies of Mainland China, while Hong Kong and Macau have their own policies. Vehicle engines as well as vehicular fuels used in these cities are different and thus we expected their emissions would also differ. In Hong Kong, diesel, gasoline, and LPG are the main fuels used by vehicles. Gasoline fueled vehicles accounted for $70.4 \%$ of the total licensed vehicles, while diesel and LPG fueled vehicles accounted for $24.5 \%$ and 3.5\%, respectively (Transport Department, 2004). Euro III emission standard is in force (Environmental Hong Kong, 2002). In Macau, Zhuhai and Guangzhou, vehicles are gasoline and diesel-fueled. Guangzhou and Zhuhai vehicles have Euro II emission standards while no emission standards are required for vehicles in Macau. Fuel composition affects vehicular performance and the emissions in part because it would affect the combustion efficiency and evaporative emissions from the fuel system. In this study, we explored the implications of fuel composition on exhaust emissions and evaporative losses to the atmospheres of these major PRD cities.

\section{Methodology}

\subsection{Sampling}

A total of 35 fuel samples were collected in February 2003. Seven gasoline samples were collected from the four major oil companies in Hong Kong, five and four samples from the
Table 1. Description of roadside sampling sites in Hong Kong, Guangzhou, Zhuhai and Macau.

\begin{tabular}{|c|c|c|}
\hline City & Site & Descriptions \\
\hline Hong Kong & $\begin{array}{l}\text { Causeway } \\
\text { Bay }\end{array}$ & $\begin{array}{l}\text { Commercial center of Hong } \\
\text { Kong, high-rise shopping mall } \\
\text { along the street, heavy traffic } \\
\text { flow in this area, frequent traffic } \\
\text { jam in rush hours. }\end{array}$ \\
\hline Guangzhou & $\begin{array}{l}\text { Tainhe } \\
\text { Zhongshan } \\
\text { University }\end{array}$ & $\begin{array}{l}\text { Tainhe is a commercial area } \\
\text { with high-rise buildings along } \\
\text { the street, Zhongshan Univer- } \\
\text { sity is located in residential area } \\
\text { with low-rise building located } \\
\text { around it, both sites have mod- } \\
\text { erate traffic flow. }\end{array}$ \\
\hline Zhuhai & $\begin{array}{l}\text { A secondary } \\
\text { school in the } \\
\text { city }\end{array}$ & $\begin{array}{l}\text { This site is located outside a } \\
\text { school, medium-rise buildings } \\
\text { on both side of road, heavy traf- } \\
\text { fic flow, stop-and-go traffic. }\end{array}$ \\
\hline Macau & $\begin{array}{l}\text { Entrance of } \\
\text { Macao-Taipa } \\
\text { Bridge }\end{array}$ & $\begin{array}{l}\text { Close to the entrance of the } \\
\text { Macau-Taipa bridge, non- } \\
\text { blocked area, heavy traffic } \\
\text { flow. }\end{array}$ \\
\hline
\end{tabular}

two main oil companies in Guangzhou and Zhuhai, respectively, and three samples from three oil companies in Macau. Four diesel samples were collected from four oil companies in Hong Kong, three samples from two oil companies in Guangzhou, two samples from two oil companies in Zhuahi, and another two samples from two oil companies in Macau. LPG is only commonly used in Hong Kong as an automobile fuel and thus five samples were collected from the five oil companies supplying LPG in this city.

Samples were collected in pre-cleaned and pre-evacuated 2-L stainless steel canisters. Details of canister cleaning procedures are given in Sive (1998). Canisters were supplied by the Rowland and Blake Laboratory at the University of California, Irvine (UCI). Fuel oils were filled into glass bottles from the oil refueling stations, and transported back to laboratory immediately. One drop of fuel oil was introduced into a given pre-evacuated canister by syringe and the measurements were based on the evaporation of the fuel inside the canister. This sampling approach depends on vapor pressure of each fuel component and thus it tends to underestimate the heavier, less volatile hydrocarbons.

In addition to auto-exhaust, evaporative loss of unburned fuel is an important emission source from automobiles (Na et al., 2004). Roadside samples were collected in Hong Kong and Guangzhou in 2000, Macau in 2002 and Zhuhai in 2003 to study the impact of evaporative losses on roadside atmospheres. Two roadside samples were collected in each city. 
The roadside samples were collected such that they were as far away as possible from direct emission sources other than vehicular emission. A description of the roadside sampling sites is shown in Table 1 . We note that LPG was not a commonly used automobile fuel in Hong Kong in 2000. Therefore, to investigate the vehicular LPG leakage, two sets of data that were collected in Hong Kong tunnels at later dates were used for comparison. The first set of data was collected in 2001 when LPG was first introduced as a fuel for taxis. The second set of data was collected in 2003 when nearly all taxis were fueled with LPG. We estimated that there was an $40 \%$ increment in LPG fueled vehicles during this period. Samples were obtained during a 10-20 min period using a mass flow controller. The results were used to study the effects of fuel evaporation on roadside and tunnel atmospheres for fuels of different hydrocarbon composition. Emission standards for vehicle fuel were similar between 2000 and 2003 in each of the four cities. Thus, it is expected that the main constituents of fuel except the fuel additives did not change much within this period.

\subsection{Chemical analysis}

All collected samples were shipped back to UCI for VOC analysis. A total of 53 non-methane hydrocarbons (NMHCs) were quantified for the fuel samples. These include $27 \mathrm{C}_{2}$ $\mathrm{C}_{10}$ saturated hydrocarbons, $13 \mathrm{C}_{2}-\mathrm{C}_{5}$ unsaturated hydrocarbons and $13 \mathrm{C}_{6}-\mathrm{C}_{10}$ aromatics. For the roadside and tunnel samples, $13 \mathrm{C}_{2}-\mathrm{C}_{8}$ saturated hydrocarbons, $5 \mathrm{C}_{2}$ $\mathrm{C}_{5}$ unsaturated hydrocarbons and $6 \mathrm{C}_{6}-\mathrm{C}_{8}$ aromatics were quantified and selected for discussion. The full details of the chromatographic system are described in Colman et al. (2001). The analytical system used for gases discussed here consisted of three gas chromatographs that housed two flame ionization detectors (FIDs) and one mass selective detector. Detailed description of methods used for determining the measurement precision and accuracy are presented in Colman et al. (2001). The accuracy for the discussed NMHCs is $5 \%$. The measurement precision varies for different compound and for different mixing ratio. Measurement precision was $3 \%$ for all gases discussed. The limit of detection for all NMHCs was 50 pptv for fuel samples and $10 \mathrm{pptv}$ for roadside and tunnel samples.

\section{Result and discussion}

In this study, a total of 53 VOCs were quantified for the evaporative portion of automobile fuels used in Hong Kong, Guangzhou, Macau and Zhuhai. Mixing ratios of individual compounds in the fuel samples varied greatly from canister to canister because of the non-quantitative way the fuel was transferred to the canisters. Therefore, individual VOCs are discussed and reported as percent hydrocarbon composition. In order to investigate VOC characteristics of different fuels,
Table 2. Summary of all the fuel profiles in percent by identified compounds ( \pm S.D.) by different hydrocarbon groups.

\begin{tabular}{lllll}
\hline & $n$ & Saturated & Unsaturated & Aromatics \\
\hline Hong Kong diesel & 4 & $40.7 \pm 4.7$ & $2.3 \pm 1.4$ & $57.1 \pm 5.8$ \\
Guangzhou diesel & 3 & $53.8 \pm 10.0$ & $3.9 \pm 1.6$ & $42.3 \pm 8.4$ \\
Zhuhai diesel & 2 & $57.4 \pm 5.3$ & $0.6 \pm 0.2$ & $41.9 \pm 5.5$ \\
Macau diesel & 2 & $64.3 \pm 1.6$ & $7.0 \pm 1.0$ & $28.8 \pm 2.0$ \\
Hong Kong gasoline & 7 & $60.4 \pm 13.2$ & $9.4 \pm 5.3$ & $30.2 \pm 12.7$ \\
Guangzhou gasoline & 5 & $57.7 \pm 8.0$ & $15.4 \pm 6.7$ & $26.9 \pm 10.7$ \\
Zhuhai gasoline & 4 & $62.0 \pm 7.7$ & $12.0 \pm 2.9$ & $27.5 \pm 1.6$ \\
Macau gasoline & 3 & $56.2 \pm 7.1$ & $8.3 \pm 0.9$ & $35.5 \pm 7.4$ \\
Hong Kong LPG & 5 & $97.6 \pm 2.1$ & $2.3 \pm 2.2$ & $0.1 \pm 0.2$ \\
\hline
\end{tabular}

$n$ : number of samples collected

the 53 VOCs were divided into three categories: saturated hydrocarbons, unsaturated hydrocarbons, and aromatic hydrocarbons. Table 2 shows a summary of all the fuel profiles (in percent composition) for different hydrocarbon groups. Source profiles of these evaporative portions of fuels were constructed and are believed to be the first reported for the PRD region. We anticipate this information will be useful in assessing vehicular fuel evaporative losses, exhaust emissions and perhaps for source apportionment within this region.

\subsection{Characteristics of diesel used in the PRD}

Diesel is a mixture of hydrocarbons with higher density, viscosity and sulfur content than gasoline and is often difficult and expensive to improve its quality. Diesel-powered vehicles are commonly used in the PRD, and in Hong Kong they include buses, public light buses and goods vehicles. These vehicles account for about one quarter of the total licensed vehicles (Transport Department, 2004).

Aromatics were the most abundant hydrocarbon group $(57.1 \% \pm 5.8 \%)$ in the four diesel fuels collected in Hong Kong, followed by saturated and unsaturated hydrocarbons $(40.7 \% \pm 4.7 \%$ and $2.3 \% \pm 1.5 \%$, respectively; Table 2$)$. By contrast, saturated hydrocarbons were the most abundant group in the diesels used in Guangzhou, Zhuhai and Macau $(53.8 \%-64.3 \%)$. The hydrocarbon group distributions for the diesel samples collected in Guangzhou and Zhuhai, the Chinese Mainland cities, were very similar.

Figure 2 shows the fuel vapor profiles (only 34 species of interest are included) of diesel collected in Hong Kong, Guangzhou, Zhuhai and Macau. Heavy hydrocarbons, namely $\mathrm{C}_{8}-\mathrm{C}_{10}$ alkanes and aromatics, contributed between $50 \%-70 \%$ of the total VOCs in the diesel samples from these four cities. These heavy portions have low vapor pressures and thus do not readily evaporate into the atmosphere. The composition of the diesel collected in Macau was slightly different from those in the other three cities. Although heavy 


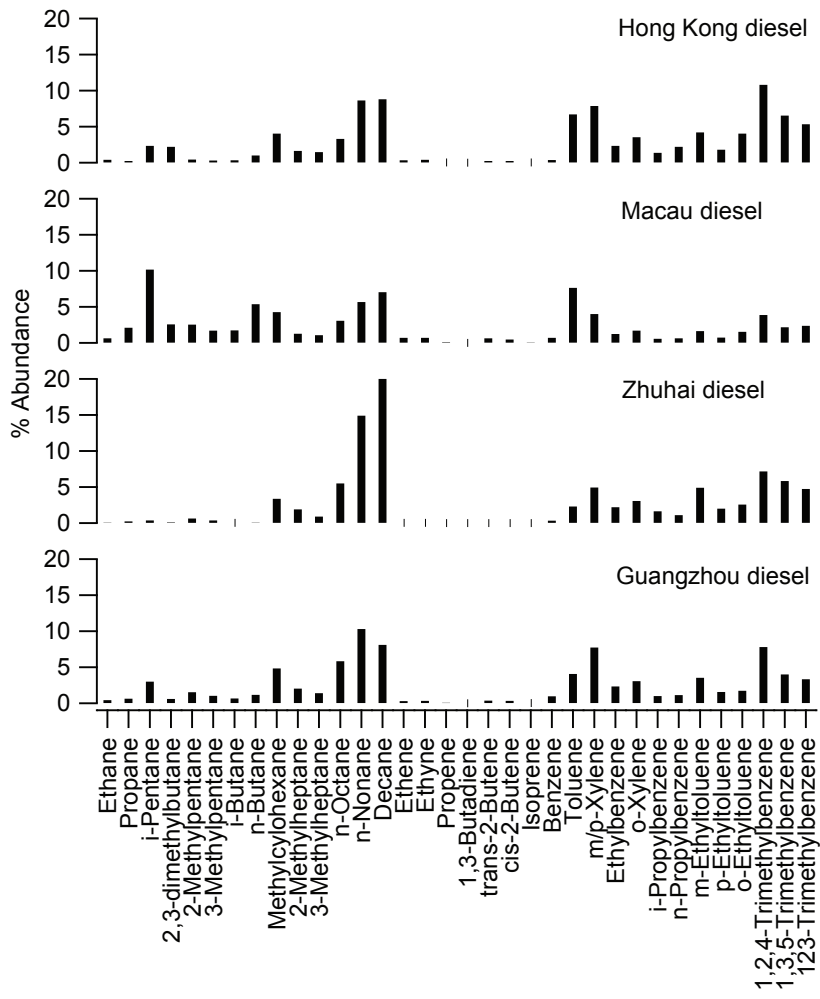

Fig. 2. The percentage compositions of diesel collected in Hong Kong, Guangzhou, Zhuhai and Macau.

hydrocarbons were still the main components, i-pentane $(10.2 \%)$, toluene $(7.6 \%)$ and n-butane $(5.4 \%)$ were also abundant in Macau's diesel.

\subsection{Characteristics of gasoline used in the PRD}

Gasoline is the fuel that is commonly used by private cars. Saturated hydrocarbons were the most abundant hydrocarbon group in all gasoline samples, contributing about $60 \%$ of the total VOCs compared to $8 \%-15 \%$ for unsaturated species and $23 \%-35 \%$ for aromatics (Table 2). The relatively high aromatic fraction in gasoline enhances its combustion performance but generally at the expense of an increase in the $\mathrm{NO}_{\mathrm{x}}$ emissions (Wang et al., 2001). Different from diesel, the gasoline used in the PRD is mainly comprised of light hydrocarbons ranging from $\mathrm{C}_{4}-\mathrm{C}_{7}$, with i-pentane, n-pentane, 2,3dimethylbutane and 2-methylpentane being the most abundant saturated species (Table 3). Although octane additives are added to unleaded gasoline to increase its octane index, n-octane did not rank among the top ten hydrocarbons in the gasoline samples. Toluene was the most abundant aromatic in the gasoline samples, comprising about half of the quantified aromatic content. Toluene is a commonly used gasoline additive and the amount of toluene added varies with different oil companies. The toluene percent composition for gasoline collected in Macau, Hong Kong, Zhuhai and Guangzhou was $24 \%, 21 \%, 14 \%$, and $10 \%$, respectively (Table 3) and all were significant higher than values reported from US, Canada and Korea (Conner et al., 1995; Mclaren et al., 1996; $\mathrm{Na}$ et al., 2004).

Toluene and i-pentane were the top two abundance compounds in gasoline collected in all the four cities as shown in Table 3. The average toluene/benzene (T/B) ratios were $22.1 \pm 12.7$ in the gasoline used in Hong Kong, and the values were $3.7 \pm 1.5,3.9 \pm 0.7$ and $23.0 \pm 1.8$ in Guangzhou, Zhuhai and Macau, respectively. The T/B ratios in gasoline measured in Hong Kong and Macau were even higher than the relatively high T/B ratios of 7-11 found at a roadside microenvironment in Hong Kong (Ho et al., 2004).

The benzene content in vehicular fuels is a concern because it is carcinogenic. Therefore a significant effort has been made to reduce benzene levels in gasoline. The benzene content measured in the gasoline used in Hong Kong and Macau was very low (around 1\%). The low benzene in the Hong Kong samples is due to the restrictions imposed by the government (the benzene content allowed in Hong Kong gasoline went from 5\% to $1 \%$ in 2000; Environmental Protection Department, 2001). In Zhuhai and Guangzhou the benzene contributions were much higher $3 \%$ and $7 \%$, respectively). Thus, the higher T/B ratios of gasoline collected in Hong Kong and Macau compared to those collected in Guangzhou and Zhuhai were mainly due to the higher toluene as well as their much lower benzene content. The high benzene levels in Guangzhou and Zhuhai gasoline exceed the EURO III standard (1\%), as well as the national specification for unleaded gasoline (2.5\%) issued by the State Environmental Protection Administration of China (SEPA).

\subsection{Characteristics of LPG used in the PRD}

Liquefied Petroleum Gas (LPG) is primarily a mixture of butanes and propane. The typically low aromatic and unsaturated hydrocarbon component of LPG leads to low levels of VOC emissions in the atmosphere from LPG fueled vehicles (Perry and Gee, 1995). According to the Hong Kong Environmental Protection Department, pollutants emitted from motor vehicles are often trapped between the very tall buildings and accumulated along the streets in Hong Kong. In 2000, the Hong Kong Government implemented a subsidy program to switch diesel taxis to LPG taxis in order to reduce the impact of smoke, $\mathrm{NO}_{\mathrm{x}}$ and $\mathrm{VOC}$ emissions on the street level air pollution in Hong Kong (Environmental Protection Department, 2001). Nearly all (99.8\%) of the 18000 taxis in Hong Kong and $80 \%$ of newly registered public light buses were LPG powered in 2003. These two types of vehicles run long hours and generate high total vehicle trip mileage (Transport Department, 2005). As a result, LPG is now primarily used as an automobile fuel in Hong Kong, with comparatively minor and decreasing cooking and heating use. From samples collected at various LPG distribution sites we determined that about $98 \%$ of the LPG sold 
Table 3. Top 10 abundant VOC species in the gasoline samples collected in Hong Kong, Guangzhou, Zhuhai and Macau.

\begin{tabular}{lcllllll}
\hline Zhuhai & $\%$ & Guangzhou & $\%$ & Hong Kong & $\%$ & Macau & $\%$ \\
\hline Toluene & 16.0 & i-Pentane & 11.3 & Toluene & 21.3 & Toluene & 24.2 \\
i-Pentane & 9.2 & Toluene & 10.0 & i-Pentane & 14.6 & i-Pentane & 16.0 \\
2-Methylpentane & 8.0 & Benzene & 6.9 & 2,3-dimethylbutane & 7.8 & 2,3-dimethylbutane & 8.1 \\
2-Methylhexane & 5.7 & 2-Methylpentane & 6.5 & 2-Methylpentane & 5.4 & 2-Methylpentane & 5.3 \\
3-Methylhexane & 5.0 & 2,3-dimethylbutane & 5.5 & n-Pentane & 5.0 & n-Pentane & 4.9 \\
3-Methylpentane & 4.6 & m/p-Xylene & 5.0 & 2,2,4-Trimethylpentane & 3.6 & n-Hexane & 3.7 \\
2-Methyl-2-butene & 4.1 & 2-Methyl-2-butene & 4.8 & 3-Methylpentane & 3.6 & 3-Methylpentane & 3.5 \\
m/p-Xylene & 3.8 & n-Pentane & 4.4 & m/p-Xylene & 3.4 & m/p-Xylene & 3.5 \\
Benzene & 3.4 & 3-Methylpentane & 4.0 & n-Hexane & 3.4 & 2-Methyl-2-butene & 2.9 \\
n-Pentane & 3.1 & 2-Methylhexane & 3.5 & 2-Methyl-2-butene & 3.1 & trans-2-Pentene & 2.0 \\
\hline
\end{tabular}

Table 4. Vehicle fleet composition in different cities during period of roadside and tunnel sampling.

\begin{tabular}{llcccc}
\hline Location & Cities & Sampling Period & \multicolumn{3}{c}{ Vehicle fleet composition in \% } \\
\cline { 3 - 5 } & & & Diesel Vehicle & Gasoline Vehicle & LPG Vehicle \\
\hline \multirow{2}{*}{ Roadside } & Hong Kong & 2000 & 29.5 & 70 & 0.5 \\
& Macau & 2002 & 5 & 95 & - \\
& Guangzhou & 2000 & 20 & 80 & - \\
& Zhuhai & 2003 & 30 & 70 & 2 \\
Tunnel & Hong Kong & 2001 & 23 & 75 & 3.5 \\
& Hong Kong & 2003 & 21.5 & 75 & \\
\hline
\end{tabular}

Sources:

Hong Kong data: Transport Department, 2001, 2002, 2004.

Macau data: The Statistics and Census Service, 2003.

Guangzhou and Zhuhai data: Bureau of Statistics of Guangdong Province, 2001, 2004.

in Hong Kong were saturated hydrocarbons, with n-butane $(46.4 \%)$, propane $(26.0 \%)$, and i-butane $(22.4 \%)$ as the main constituents.

\subsection{Effect of fuel evaporative loss on the roadside and tun- nel atmosphere}

Figure 3 shows the average hydrocarbon distribution measured at roadside sites in the four cities, compared with the composition of gasoline vapors in those cities. Figure 4 shows the average hydrocarbon distribution measured in a tunnel in 2001 and 2003 in Hong Kong, compared with the composition of gasoline vapors and LPG collected in 2003. Both figures focus on the 24 VOC species that are found in relatively high amounts in the roadside and tunnel microenvironments. The distributions are presented as percent by volume of total VOCs measured. A description of vehicle fleet composition in different cities during period of roadside sampling is shown in Table 4. In Fig. 3 it is clear that there are several VOCs that were abundant in the roadside samples but not the gasoline samples, namely ethene, ethyne, propene, ethane, propane, i-butane, and n-butane.
Ethene and ethyne are typical tracers for combustion, and thus vehicle exhaust was the likely source of these two gases (Stoeckenius et al., 2006). Guo et al. (2006) concluded from receptor model analysis that vehicular emission was a dominant VOCs source in Hong Kong, accounted for $39 \%$ of total emission, while it also accounted for $32 \%$ of total VOC emission in the PRD. The ethyne/ethene ratios for Hong Kong, Macau, Guangzhou and Zhuhai were $0.53 \pm 0.03,1.06 \pm 0.04$, $1.26 \pm 0.04$ and $1.01 \pm 0.21$, respectively. We attribute these differences to variations in fuel and on-road vehicular composition, car engine, car age and maintenance, as well as emission controls used in these four cities. It was noted that Hong Kong has more new cars and the cars have better maintenance. The ethene level in the Hong Kong roadside was a factor of two higher than ethyne, whereas ethene and ethyne were close in Guangzhou, Zhuhai and Macau. This is likely the result of less strict controls of vehicular emissions in Guangzhou, Zhuhai and Macau than for those in Hong Kong.

Propane, i-butane and n-butane are tracers for LPG, which was commonly used as vehicular fuel in Hong Kong but 


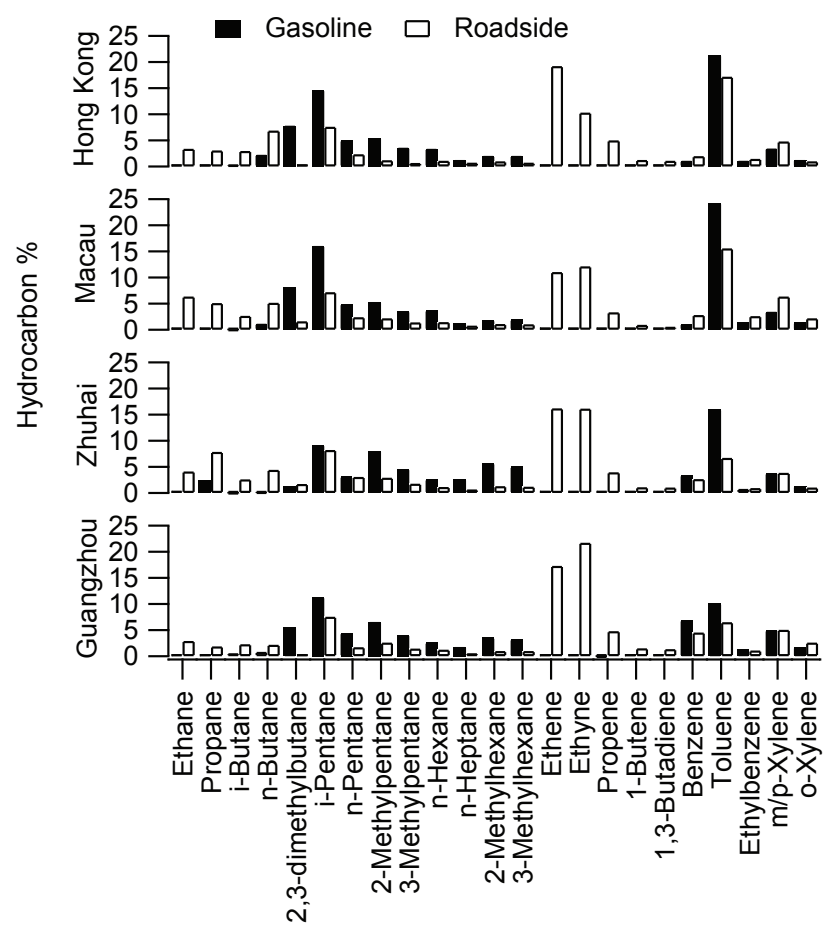

Fig. 3. Average hydrocarbon distributions (presented in percent by volume in total VOCs) for gasoline vapors and roadside sites samples in Hong Kong, Guangzhou, Zhuhai and Macau.

not the other three cities during the data collecting periods. Roadside samples for Hong Kong were collected in 2000, when LPG usage as vehicular fuel was not significant. There were still emissions from residential and commercial LPG cooking in 2000, but their usage is gradually decreasing in Hong Kong. In the PRD region, the total LPG consumption ws nearly $3.5 * 10^{6}$ tones in 2000 (Tian, 2002) and LPG was mainly consumed by heating and cooking. Hence, the presence of propane, i-butane and n-butane in our roadside air during the data collecting period in all four cities were believed to be driven by LPG leakage from refueling centres and domestic usage, and their concentration levels depended on the proximity to these LPG cooking sources. However, since August 2000, LPG has been widely used as vehicular fuel for taxis and public light buses in Hong Kong. Nearly all diesel taxis had switched to LPG and around $80 \%$ of all new public light buses were operating on LPG by 2004 (Environmental Protection Department, 2005), and it is a trend that more light buses will be replaced by LPG ones in the near future. In the PRD, Guangzhou Government started to promote the use of LPG-fueled buses and taxi in 2003 and around 2400 buses and 7500 taxis had switched to LPG at the end of 2004 (Lin and Zhao, 2005). It was concluded by Guo et al. (2006) that the heavy usage of LPG-fueled taxis in Hong Kong since 2000 contributed to the elevated propane mixing ratios in Hong Kong urban air. Unlike Hong Kong where domestic LPG usage is diminishing, statistics in Guangzhou city showed that about 686,628 tons of LPG was consumed in 2004, and 452, 138 tons of LPG were for residential use (Bureau of Statistics of Guangdong Province, 2005). It implies that emission from domestic usage of LPG other than emission from LPG-fueled vehicles still dominated in PRD in 2004. Yet, the present trend showed that contribution of LPG leakage from vehicles in this region will be increasingly important due to the increasing usage of LPG-fueled vehicles in both Hong Kong and the PRD. Elevated roadside concentrations of diesel related gases (such as n-nonane and n-decane) were not observed, suggesting that evaporative loss from diesel to the roadside atmosphere was insignificant compared with the light species from gasoline and LPG.

The concentrations of toluene and i-pentane were high in the roadside samples compared with most species other than ethene and ethyne (Fig. 3). From our previous discussion in Sect. 3.2, these gases are tracers of gasoline evaporation and their enhanced concentrations indicated the importance of running evaporative loss from gasoline-fueled vehicles in the targeted cities. Gasoline evaporation was found to contribute $14 \%$ of total VOC emission in Hong Kong in 2001-2002 (Guo et al., 2006). In addition to evaporative loss from gasoline, the i-pentane content in diesel used in Macau was high compared with those used in the other three cities (Fig. 2). Therefore evaporative losses of i-pentane from diesel used in Macau likely contributed to the elevated i-pentane levels in Macau. Unfortunately, the roadside sampling site chosen in Macau was dominated by gasoline powered vehicles, and thus the effect of evaporative loss of i-pentane from diesel cannot be fully evaluated from this study. Toluene was widely found to exist at elevated concentration levels in PRD cities. The widespread use of toluene-rich unleaded gasoline in these cities plus the evaporative loss of toluene from industrial solvents and paints in the PRD are the reasons for the elevated toluene levels (Chan et al., 2006).

The ratio of i-pentane distributions in gasoline vapor to that in roadside atmosphere [i-pentane $]_{\text {gasoline }} /[\mathrm{i}-$ pentane $]_{\text {roadside }}$ is calculated and used to study the degree of gasoline evaporation in different cities. This ratio is generally little affected by emissions from diesel and LPG vehicles. The average $[i-p e n t a n e]_{\text {gasoline }} /[i-p e n t a n e]_{\text {roadside }}$ in Hong Kong, Macau, Zhuhai and Guangzhou was 1.9, 2.2, 1.4 and 1.5, respectively. The ratios measured in Guangzhou and Zhuhai were closer to unity than those of Hong Kong and Macau. Chan et al. (2002) found that the vehicles in China were usually with poor emission controls and poor vehicle maintenance. We contend that this indicates a higher degree of gasoline evaporation from vehicles to the roadside atmosphere in Guangzhou and Zhuhai, likely the result of less effective fuel system maintenance.

In order to study the evaporative loss of LPG from vehicles in Hong Kong, the hydrocarbon profiles of tunnel samples collected in Hong Kong in 2001 are compared with those collected in 2003 (Fig. 4). We estimated that around $60 \%$ of the 18000 taxis had switched to LPG powered during our 
tunnel sampling period in July 2001, and the percentage increased to $99.8 \%$ at the end of 2003 . Besides, the 4350 public light buses were encouraged to switch to LPG powered in 2002, and over $80 \%$ of newly registered public light buses were LPG powered by the end of 2003 (around 10\% of the total registered public light buses). There was around $40 \%$ increase of LPG powered vehicles from 2001 to 2003. The contribution of gases associated with LPG (propane, i-butane and n-butane) to total VOCs increased in the samples collected in 2003. The propane/butanes ratio of LPG (obtained from source samples) was 0.38 , and the ratios of the tunnel samples collected in 2001 and 2003 were 0.22 and 0.40 , respectively. Trucks transporting LPG tanks are banned from traveling through tunnels in Hong Kong. The very similar propane/butanes ratio obtained in the 2003 tunnel samples and the LPG source samples indicates that the propane and butanes measured in the tunnel in 2003 resulted from running evaporative losses of LPG. These findings are consistent with the $40 \%$ increase of LPG fueled taxis and public light buses using Hong Kong tunnels. An increased toluene distribution (T/B ratio) from year 2001 to 2003 was also observed from the tunnel data reflecting the increase use of toluene as an octane-raising additive in gasoline in recent years.

\section{Conclusions}

Based on collected fuel samples, hydrocarbon profiles were constructed for the evaporative portion of three kinds of vehicular fuels (gasoline, diesel and LPG) commonly used in major PRD cities. It was found that all types of sampled diesels consisted mainly of heavy $\left(\mathrm{C}_{8}-\mathrm{C}_{10}\right)$ hydrocarbons $\left(\mathrm{C}_{10}\right.$ being the heaviest hydrocarbon quantified). These compounds have low vapor pressures and thus do not quickly evaporate into the atmosphere. Interestingly, diesel fuels collected in Macau had relatively high amounts of i-pentane, toluene and n-butane in addition to the heavy hydrocarbons. All gasoline samples collected were rich in alkanes, mainly $\mathrm{C}_{4}-\mathrm{C}_{7}$ hydrocarbons. Toluene and i-pentane were the two main constituents of gasoline and they were used as tracers for estimating gasoline evaporative losses. The benzene content in gasoline collected in Hong Kong meets the requirement of the Hong Kong SAR government (1\% benzene in unleaded gasoline). However, the benzene contents in gasoline collected in Zhuhai and Guangzhou were higher than the Chinese SEPA standard (2.5\% benzene). LPG samples were only collected in Hong Kong and were comprised primarily of n-butane (46.4\%), propane (26.0\%) and i-butane (22.4\%).

Roadside samples collected in the four cities from year 2000 to 2003 were examined. The VOC characteristics of the roadside samples were compared with the gasoline and diesel samples collected from the same city. Several combustionrelated gases (ethene, ethyne, ethane and propene) were found predominantly in the roadside atmospheres, while they were only minor or negligible constituents in the gasoline
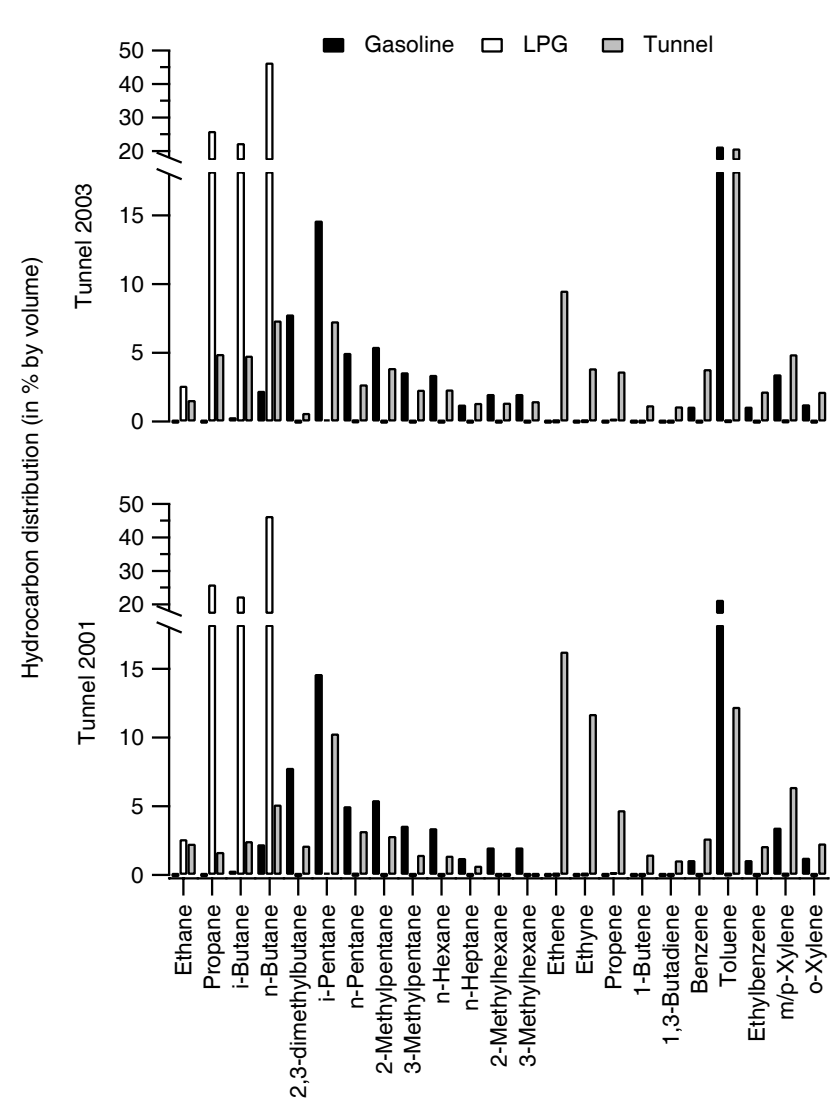

Fig. 4. Average hydrocarbon distributions (presented in percent by volume in total VOCs) for gasoline vapor, LPG and tunnel samples in Hong Kong in 2001 and 2003.

and diesel samples. Propane, i-butane and n-butane were also present in some roadside samples in 2000, and are believed to be from cooking activities. Evaporative loss from diesel was found to be insignificant in PRD compared to losses from gasoline and LPG. Evaporative loss of gasoline was responsible for the high i-pentane and toluene concentrations in the roadside atmospheres, while industrial uses of solvent and paint also contributed to the emission of toluene in the ambient atmosphere. The $[i-\text { pentane }]_{\text {gasoline }} /[i-\text { pentane }]_{\text {roadside }}$ ratio was used to assess the degree of gasoline evaporative loss to the atmosphere. Higher degrees of evaporative loss were observed in Guangzhou and Zhuhai than in Hong Kong and Macau. The similar propane/butanes ratios measured for LPG source and tunnel samples ( 0.38 and 0.40 , respectively) in 2003 illustrated the impact of evaporative losses from LPG fueled vehicles, and are consistent with increased LPG usage in Hong Kong beginning in 2001. 
Acknowledgements. This project is supported by research grants (G-W013, ASD 504) from the Hong Kong Polytechnic University, PolyU 5048/02E and PolyU 5131/04E from the Research Grants Council of Hong Kong, and the Comer Foundation. The authors would like to thank all coworkers for sampling and chemical analysis.

Edited by: R. Volkamer

\section{References}

Blake, D. R. and Rowland, F. S.: Urban leakage of liquefied petroleum gas and its impact on Mexico city air quality, Science, 269(5226), 953-956, 1995.

Bureau of Statistics of Guangdong Province: Guangzhou Statistical Yearbook 2005, China Statistics Press, 2005.

Bureau of Statistics of Guangdong Province: Statistical yearbook of Guangdong 2001, China Statistics Press, 2001.

Bureau of Statistics of Guangdong Province: Statistical yearbook of Guangdong 2004, China Statistics Press, 2004.

Chan, L. Y., Chu, K. W., Zou, S. C., Chan, C. Y., Wang, X. M., Barletta, B., Blake, D. R., Guo, H., and Tsai, W. Y.: Characteristics of nonmethane hydrocarbons (NMHCs) in industrial, industrialurban, and industrial-suburban atmospheres of the Pearl River Delta (PRD) region of south China, J. Geophys. Res., 111, D11304, doi:10.1029/2005JD006481, 2006.

Chan, L. Y., Lau, W. L., Zou, S. C., Cao, Z. X., and Lai, S. C.: Exposure level of carbon monoxide and respirable suspended particulate in public transportation modes while commuting in urban area of Guangzhou, China, Atmos. Environ., 36, 5831-5840, 2002.

Chen, T. Y., Simpson, I. J., Blake, D. R., and Rowland, F. S.: Impact of the leakage of liquefied petroleum gas (LPG) on Santiago air quality, Geophys. Res. Lett., 28(11), 2193-2196, 2001.

Colman, J. J., Swanson, A. L., Meinardi, S., Sive, B. C., Blake, D. R., and Rowland, F. S.: Description of the analysis of a wide range of volatile organic compounds in whole air samples collected during PEM-tropics A and B, Anal. Chem., 73(15), 37233737, 2001.

Conner, T. L., Lonneman, W. A., and Seila, R. L.: Transportationrelated volatile hydrocarbon source profiles measured in Atlanta, Journal of the Air \& Waste Management Association, 45, 383394, 1995.

Environmental Protection Department: Environmental Hong Kong 2001, Environmental Protection Department of Hong Kong SAR, 2001.

Environmental Protection Department: Environmental Hong Kong 2002, Environmental Protection Department of Hong Kong SAR, 2002.
Environmental Protection Department: Environmental Hong Kong 2005, Environmental Protection Department of Hong Kong SAR, 2005.

Guo, H., Wang, T., Blake, D. R., Simpson, I. J., Kwok, Y. H., and Li, Y. S.: Regional and local contributions to ambient nonmethane volatile organic compounds at a polluted rural/coastal site in Pearl River Delta, China, Atmos. Environ., 40, 23452359, 2006.

Ho, K. F., Lee, S. C., Guo, H., and Tsai, W. Y.: Seasonal and diurnal variations of volatile organic compounds (VOCs) in the atmosphere of Hong Kong, Sci. Total Environ., 322(1-3), 155-166, 2004.

Lin, Y. L. and Zhao, S. G.: Future development of clean vehicle in Shenzhen, Urban Gas, (in Chinese), 363(5), 8-11, 2005.

Mclaren, R. M., Gertler, A. W., Wittorff, D. N., Belzer, W., Dann, T., and Singleton, D. L.: Real-world measurements of exhaust and evaporative emissions in the Cassiar tunnel predicted by chemical mass balance modeling, Environ. Sci. Technol., 30, 3001-3009, 1996.

Na, K., Kim, Y. P., Moon, I., Moon, K. C.: Chemical composition of major VOC emission sources in the Seoul atmosphere, Chemosphere, 55, 585-594, 2004.

Perry, R. and Gee, I. L.: Vehicle emissions in relation to fuel composition, The Science of the Total Environment, 169, 149-156, 1995.

Sive, B. C.: Atmospheric nonmethane hydrocarbons: analytical methods and estimated hydroxyl radical concentrations, $\mathrm{PhD}$ dissertation, University of California, Irvine, 1998.

Stoeckenius, T. E., Ligocki, M. P., Shepard, S. B., and Iwamiya, R. K.: Analysis of PAMS data: application to summer 1993 Houston and Baton Rouge data, Draft report prepared by Systems Applications International, San Rafael, CA, SYSAPP 94-95/115d, November, in: USEPA report: Receptor Modeling, 2006.

The Statistics and Census Service: Macau In Figure 2003, Government of Macau Special Administrative Region, 2003.

Tina, C. R.: Rapid expansion of liquefied petroleum gas market in China, International Petroleum Economy, 10(5), 30-33, 2002.

Transport Department: Annual Transport Digest 2001, The Transport Department of Hong Kong SAR, 2001.

Transport Department: Annual Transport Digest 2002, The Transport Department of Hong Kong SAR, 2002.

Transport Department: Annual Transport Digest 2004, The Transport Department of Hong Kong SAR, 2004.

Traffic Department: Monthly traffic and transport digest, The Transport Department of Hong Kong SAR, 2005.

Wang, S. X., Shao, M., and Zhang, Y. H.: Influence of fuel quality on vehicular $\mathrm{NO}_{\mathrm{X}}$ emissions, J. Environ. Sci., 13, 265-271, 2001. 